\title{
Evaluation of the efficacy of neonicotinoid and pyrethroid insecticides in Diaphorina citri Kuwayama (Hemiptera: Liviidae) populations in Colombia
}

\section{Evaluación de la eficacia de insecticidas neonicotinoides y piretroides sobre poblaciones de Diaphorina citri Kuwayama (Hemiptera: Liviidae) en Colombia}

AUGUSTO RAMÍREZ-GODOY

GINA PUENTES-PÉREZ

HERMANN RESTREPO-DÍAZ1,

Diaphorina citri in 'Tahiti' lime.

Photo: A. Ramírez-Godoy

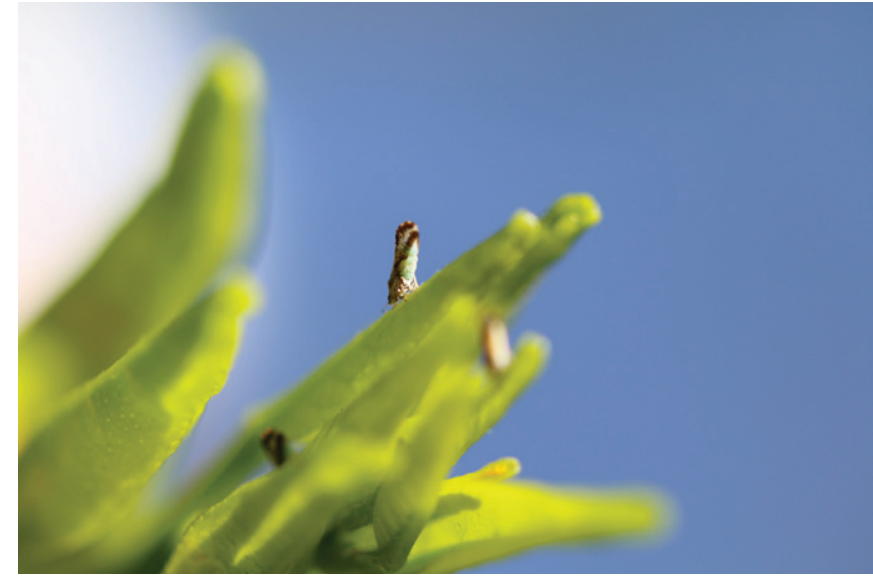

\begin{abstract}
The Asian citrus psyllid Diaphorina citri is the insect vector of the disease known as huanglongbing (HLB), which is the most devastating disease of citrus crops in the world. The Asian citrus psyllid was officially reported in Colombia in 2007, and a national phytosanitary emergency was declared because of the presence of HLB in 2015. Two different experiments were carried out in two locations (Apulo and Jerusalén, Department of Cundinamarca) in Colombia to evaluate the effectiveness of neonicotinoid (clothianidin, imidacloprid and thiamethoxan) and pyrethroid applications (bifenthrin, deltamethrin and lambda cyhalothrin) on the control of $D$. citri populations (adults, nymphs and eggs) in 'Tahiti' lime trees established under tropical dry forest conditions. In the first experiment, trees were foliarly treated as follows: (1) untreated trees; (2) trees treated with $100 \mathrm{~g} \mathrm{ha}^{-1}$ of imidacloprid; (3) trees treated with $60 \mathrm{~g} \mathrm{ha}^{-1}$ of bifenthrin; (4) trees treated with $12.5 \mathrm{~g} \mathrm{ha}^{-1}$ of deltamethrin and (5) trees treated with a co-formulation of $70 \mathrm{~g} \mathrm{ha}^{-1}$ of a neonicotinoid (thiametoxan) and $53 \mathrm{~g} \mathrm{ha}^{-1}$ of a pyrethroid (lambda cyhalothrin). In the second experiment, trees were treated with $100 \mathrm{~g}$ ha ${ }^{-1}$ of clothianidin. Foliar insecticide applications were carried out at 0 and 4 weeks after the initiation of treatments (WAT). In the first trial, the control presented a mean number of individuals per flush of $\approx 1.14$, whereas the trees treated with neoinicotinoids and pyrethroids showed $50 \%$ fewer individuals $(0.53-0.61)$. For the population of immatures, the number of nymphs was 2.25 nymphs per flush in the control, as compared to 0.82-1.22 individuals observed in the treatments with insecticides. The mean number of eggs was

\footnotetext{
Faculty of Agricultural Sciences, Department of Agronomy, Universidad Nacional de Colombia, Bogota (Colombia). ORCID Ramírez-Godoy, A.: 0000-0003-4347-8170; ORCID Puentes-Pérez, G.: 0000-0003-1839-4960; ORCID Restrepo-Díaz, H.: 0000-0002-1838-5872
}

2 Corresponding author.hrestrepod@unal.edu.co
\end{abstract}


also between $80-100 \%$ higher in the control trees (2.37 individuals), as compared to the treated trees (1.14-1.78). In the second trial, the use of clothianidin showed a higher control of eggs. The results suggest that the rotation of neonicotinoids with pyrethroids can be a tool to reduce populations and delay resistance processes in $D$. citri in citrus trees established under tropical dry forest conditions in Colombia.

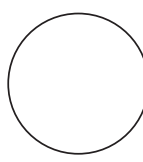

Additional key words: Asian Citrus Psyllid, greening, insecticide resistance, insecticide rotation, percentage of efficacy.

\section{RESUMEN}

El psílido asiático de los cítricos Diaphorina citri es el insecto vector de la enfermedad conocida como huanglonbing (HLB), la cual es la enfermedad más devastadora de estos cultivos en el mundo. El psílido asiático de los cítricos fue reportado oficialmente en Colombia en 2007 y se declaró la emergencia nacional fitosanitaria por HLB en 2015. Con el objetivo de estudiar estrategias de manejo del insecto vector, se llevaron a cabo dos experimentos diferentes en dos localidades (Apulo y Jerusalén, Departamento de Cundinamarca) en Colombia, en los que la efectividad de aplicaciones de neonicotinoides (clothianidin, imidacloprid y thiametoxan) y piretroides (bifentrina, deltametrina y lambdacialotrina) fue evaluada sobre poblaciones de D. citri (adultos, ninfas y huevos) en árboles de lima 'Tahití' establecidos en condiciones de bosque seco tropical. En el primer experimento, los árboles fueron tratados foliarmente de la siguiente manera: (1) árboles sin tratar; (2) árboles tratados con imidacloprid a una dosis $100 \mathrm{~g} \mathrm{haa}^{-1}$ i.a; (3) árboles tratados con bifentrina a una dosis de $60 \mathrm{~g} \mathrm{ha}^{-1}$ i.a; (4) árboles tratados con deltametrina a 12,5 g ha- ${ }^{-1}$ i.a y (5) una coformulación de thiametoxan y lambda-cyalothrina a una dosis de $70 \mathrm{~g}_{\text {ha }}{ }^{-1}$ i.a. El segundo experimento consistió en árboles tratados con clothianidin a $100 \mathrm{~g} \mathrm{ha}^{-1} \mathrm{i}$.a. Las aplicaciones foliares de los insecticidas fueron desarrolladas a las 0 y 4 semanas de iniciados los tratamientos (SIT). En el primer ensayo, el control presentó $\approx 1,14$ individuos promedio por brote, mientras los árboles tratados con neoinicotinoides y piretroides mostraron un $50 \%$ menos de individuos $(0,53-0,61)$. Con respecto a la población de inmaduros, el número de ninfas promedio fue 2,25 ninfas por brote en el control comparado a los 0,82-1,22 individuos observados en los tratamientos con insecticidas. El número de huevos promedio también fue entre un $80-100 \%$ mayor en árboles control (2,37 individuos) en comparación a árboles tratados $(1,14-1,78)$. Con respecto al segundo ensayo, el uso de clothianidin presentó un mayor control de huevos. Los resultados obtenidos permiten sugerir que la rotación de neonicotinoides con piretroides puede ser una herramienta para reducir las poblaciones del psílido asiático de los cítricos y retrasar procesos de resistencia del vector en cultivos de cítricos establecidos en condiciones de bosque seco tropical en Colombia.

Palabras clave adicionales: psílido asiático de los cítricos, greening, resistencia a insecticidas, rotación de insectidas, porcentaje de eficacia.

Fecha de recepción: 14-03-2018 Aprobado para publicación: 30-05-2018

INTRODUCTION

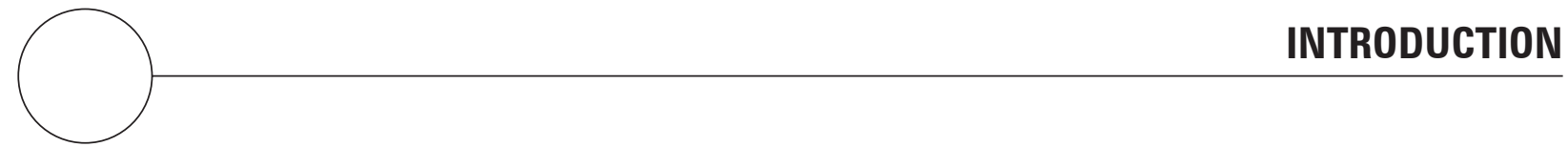

The Asian Citrus Psyllid (ACP) Diaphorina citri Kuwayama (Hemiptera: Liviidae) is the vector of the bacterium Candidatus Liberibacter asiaticus, which is the cause of the huanglongbing disease (HLB) (also known as citrus greening) (Cocco and Hoy, 2008). ACP is mainly associated with species of the Rutaceae family (especially limes and lemons) and feeds directly on the phloem content of young flushes (Boina and Bloomquist, 2015).

ACP was officially reported in Colombia in 2007 (Santivañez et al., 2013). However, the Colombian Agricultural Institute (ICA) declared a phytosanitary emergency because of the presence of $D$. citri adults 
infected with the bacterium, which caused the HLB disease in 2015 (ICA, 2015; 2017). Consequently, citrus producers require the development of strategies for the management of the vector. In Colombia, pyrethroid and neonicotinoid insecticides may play an important role in Integrated Pest Management (IPM) programs (Sétamou et al., 2010). However, in the management of ACP there are no records of its use.

Several active ingredients have been evaluated to control ACP adults and immatures (Tiwari et al., 2011). Systemic insecticides from the group of neonicotinoids, such as clothianidin, imidacloprid and thiamethoxane, have been widely used in crop protection, showing positive results in the control of ACP populations (Elbert et al., 2008; Sétamou et al., 2010; Qureshi et al., 2014). Imidacloprid is one of the molecules widely used in management programs (Ruiz-Galván et al., 2015). Boita et al. (2015) stated that foliar applications of neonicotinoids provide the longest lasting protection (8-9 weeks), with imidacloprid having the highest adult control (50-90\%). Hernández-Fuentes et al. (2012) showed that foliar applications of imidacloprid exerted more than $85 \%$ control of ACP nymphs for $27 \mathrm{~d}$ after application. On the other hand, thiamethoxan and clothianidin are second-generation neonicotinoids that are widely used in IPM programs (Maienfisch et al., 2001). Qureshi et al. (2009) observed that thiamethoxan applications were more effective than imidacloprid in controlling ACP populations in sweet orange (Citrus sinensis). ACP has also shown susceptibility to the use of clothianidin. It has been reported that the $\mathrm{LC}_{50}$, through ingestion of clothianidin and Imidacloprid, is 0.09 parts per million (ppm) and $0.11 \mathrm{ppm}$ for thiamethoxan (Langdon and Rogers, 2017).

Insecticides of the pyrethroid group are currently the main kind of neurotoxic insecticide and are widely used in crop protection (Davies et al., 2007). Applications of several groups of pyrethroids, such as fenpropathrin (Stansly et al., 2015), cypermethrin (Boina and Bloomquist, 2015), lambda cyhalothrin (Yamamoto et al., 2009) and bifenthrin (Pardo et al., 2017), have been reported in ACP population control programs in several citrus species. In Colombia, there is great ecological diversity, which creates the need to design integrated management programs according to these varied conditions. To do so, it is necessary to study the control exerted by insecticides on D. citri populations in the different areas where this pest can develop (the insect can establish itself in both dry tropical forest areas and premontane wet and dry forests) (Ebratt-Ravelo et al., 2011). Chemical control has been a strategy that has shown positive results in the reduction of insect populations, and knowledge on the effectiveness of different active ingredients allows for rotation with the purpose of decreasing resistance within ACP populations (Sétamou et al., 2010; Boina and Bloomquist, 2015; Ruiz-Galván et al., 2015). The objective of the present study was to evaluate the effectiveness of foliar applications of neonicotinoids (clothianidin, imidacloprid and thiametoxan) and pyrethroids (bifenthrin and deltamethrin) on the control of ACP populations in 'Tahiti' lime orchards established in tropical dry forest conditions.

\section{MATERIAL AND METHODS}

\section{Neonicotinoid and pyrethroid evaluation}

Two trials were carried out separately between November 2015 and January 2016 on farms under drip irrigation conditions located in the municipalities of Apulo (4'30'44.73" N and $74^{\circ} 34^{\prime} 57.58^{\prime \prime} \mathrm{W}$, altitude: $420 \mathrm{~m}$ a.s.1.) and Jerusalén (4³3'33.91" $\mathrm{N}$ and 7441'39.09" W, altitude: $316 \mathrm{~m}$ a.s.1.) in the Department of Cundinamarca in Colombia. The climatic conditions during the two trials are presented in figure 1 . The studies were conducted on 8 and 6 years-old 'Tahiti lime' trees (Citrus latifolia Tanaka), grafted on 'Citrumelo CPB 4475' (Poncirus trifoliata $\times$ Citrus Paradisi) in Apulo and Jerusalén, respectively.

The evaluated treatments were: (1) control (trees without foliar application of any pesticide); (2) trees treated with $100 \mathrm{~g} \mathrm{ha}^{-1}$ of a neonicotinoid insecticide, imidacloprid (Confidor 350 SC; Bayer); (3) trees sprayed with $60 \mathrm{~g} \mathrm{ha}^{-1}$ of a pyrethroid insecticide, bifenthrin (Brigada ${ }^{\circledR} 100$ EC; FMC); (4) a treatment with $12.5 \mathrm{~g} \mathrm{ha}^{-1}$ of a pyrethroid insecticide, deltamethrin (Dinastia ${ }^{\circledR} 100$ EC; Bayer) and (5) a commercial insecticide co-formulation of $70 \mathrm{~g} \mathrm{ha}^{-1}$ of a neonicotinoid (thiametoxan) and $53 \mathrm{~g} \mathrm{ha}^{-1}$ of a pyrethroid (lambda cyhalothrin) (Engeo ${ }^{\circledR}$; Syngenta).

\section{Clothianidin evaluation}

Two experiments were also carried out between January and March 2016 on the "Tortugas" and "Parcela 3" farms located in the municipality of Jerusalén (4'33'33.91" $\mathrm{N}$ and $74^{\circ} 41^{\prime} 39.09^{\prime}$ ' W, altitude: $316 \mathrm{~m}$ a.s.l.) in the Department of Cundinamarca in Colombia. The climatic conditions during the trials 


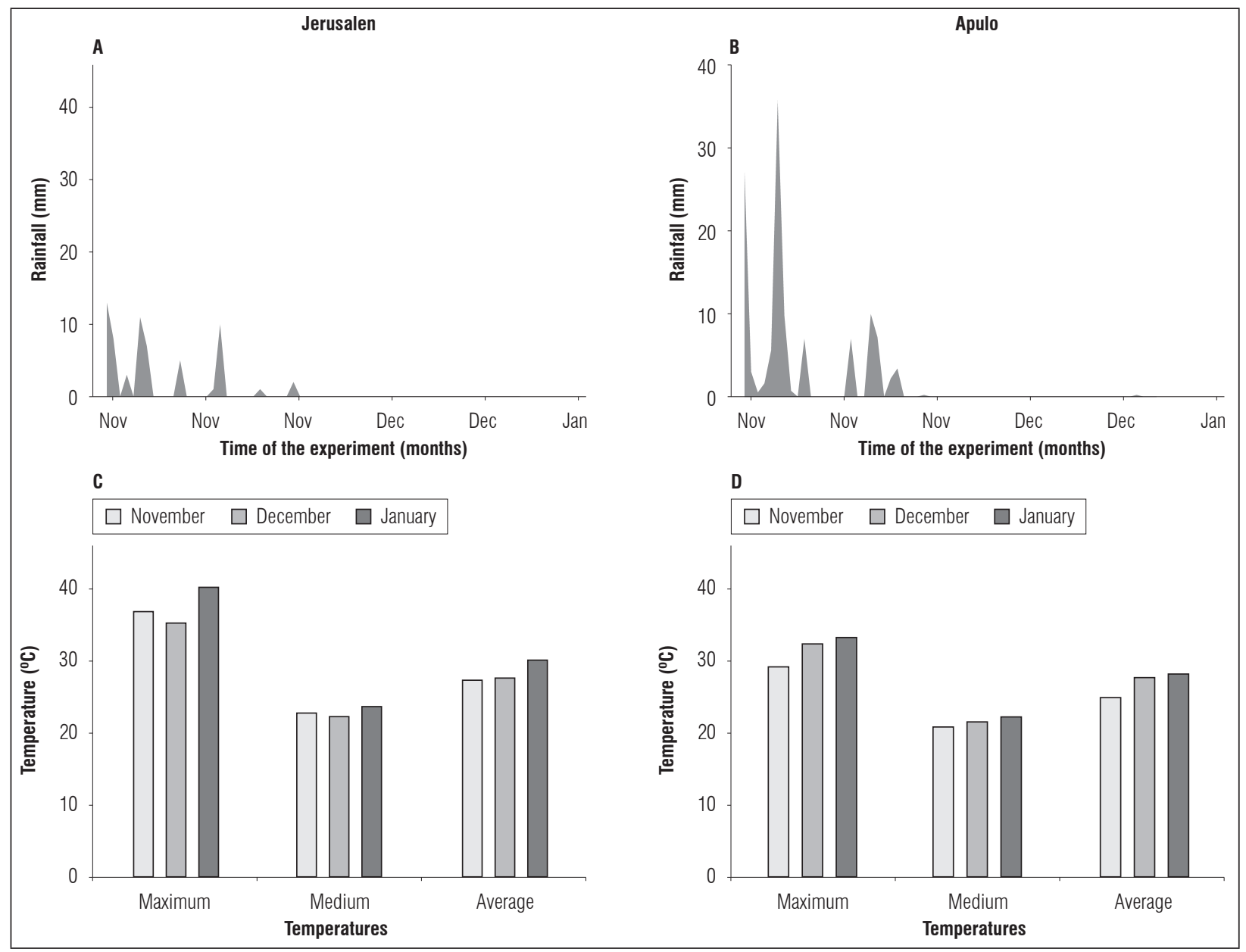

Figure 1. Rainfall records, and maximum, minimum and average temperatures for neonicotinoid and pyrethroid evaluation trials in Jerusalen ( $A$ and $C$ ) and Apulo (B and D). Data were obtained from two nearby weather stations [Jerusalen

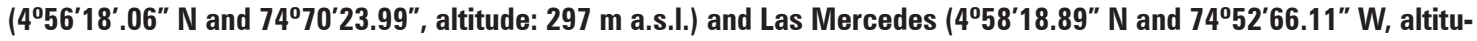
de: $810 \mathrm{~m}$ a.s.l.) stations] of the Institute of Hydrology, Meteorology and Environmental Studies of Colombia (IDEAM).

are summarized in figure 2. 'Tahiti' lime trees (Citrus latifolia Tanaka) were used, grafted on the 'Citrumelo 4475 ' pattern Poncirus trifoliata $\times$ Citrus paradisi, under drip irrigation conditions and aged 6 and 4 years, respectively. The treatments consisted of (1) control (trees without applications) and (2) trees foliarly treated with $100 \mathrm{~g}_{\mathrm{ga}}^{-1}$ of clothianidin.

In general, all trees were spaced $8 \times 5 \mathrm{~m}$ in all orchards. Also, the foliar applications of the insecticides were carried out ( $2 \mathrm{~L} /$ tree $)$ at 0 and 4 weeks after the treatments started (WAT) with a pesticide sprayer backpack (Classic model, Royal Condor, Bogota, Colombia), wetting the upper and lower surfaces of the leaves. Finally, all the experiments lasted 9 weeks.

\section{Determined variables}

The methodology described by Sétamou et al. (2008) was used to estimate the population variability of $D$. citri. The levels of $D$. citri adult, egg and nymph infestation were estimated with a random review of five young flushes per tree at the four cardinal points (north, south, east and west) on the field. Also, eggs and nymphs were counted and recorded per flush in situ using a 15X hand held lens. In general, samples were collected between 0 and 8 WAT at intervals of 7 d per sampling in all trials.

The procedure described by Henderson and Tilton (1955) was used to evaluate the efficacy of the 


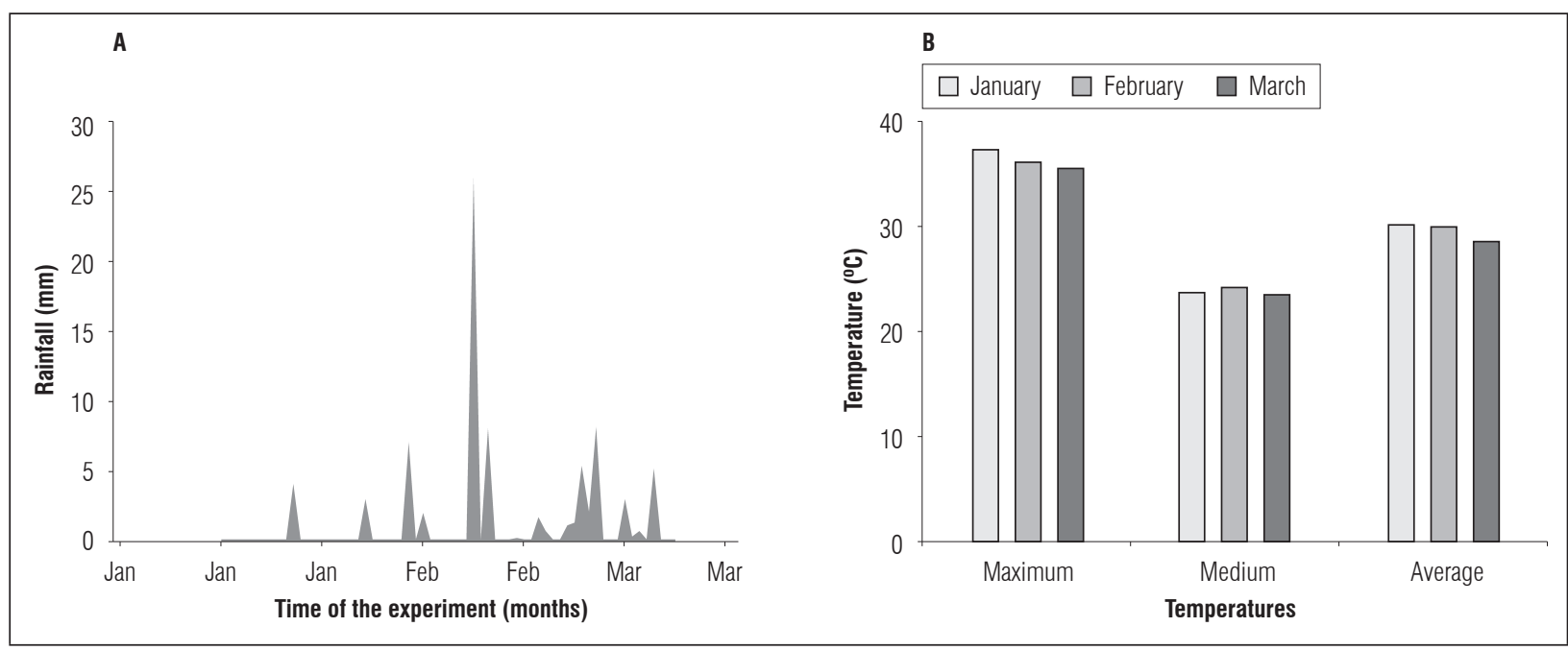

Figure 2. Rainfall records (A), and maximum, minimum and average temperatures $(B)$ for the clothianidin evaluation located in the municipality of Jerusalen. Data were obtained from a nearby weather station [Jerusalen $\left(4^{\circ} 56^{\prime} 18^{\prime} .06^{\prime \prime} \mathrm{N}\right.$ and 74070'23.99" W, altitude: 297 m a.s.l.) station] of the Institute of Hydrology, Meteorology and Environmental Studies of Colombia (IDEAM).

treatments on the development of $D$. citri populations in the neonicotinoid and pyrethroid evaluation experiment. Overall, the efficacy percentage in each treatment was determined with the following formula:

$$
\% \text { Efficacy }=100 \times\left(1-\frac{(T a \times C b)}{(T b \times C a)}\right)
$$

Where, $\mathrm{T}$ is the treated population, $\mathrm{C}$ is the control population, $\mathrm{a}$ is the population after the treatment, and $b$ is the population before the treatment.

\section{Statistical design}

A statistical design in series of experiments, with analysis in different localities, was used in the present study for both experiments (Gómez and Gómez, 1984). On each farm, the treatments were randomly arranged in four blocks. The experiment unit consisted of three trees surrounded by guard trees. To analyze the $D$. citri population, a logarithmic transformation of the data was used because they did not show a normal distribution. Data expressed as percentages were transformed using the arcsine formula. The Tukey's test of mean comparison was used when significant differences were observed in the analysis of variance. The data were analyzed using the statistical program Statistix, v. 9 (Tallahasse, FL, USA).

\section{RESULTS}

\section{Neonicotinoid and pyrethroid evaluation}

Significant differences $(P \leq 0.01)$ in the population dynamics of $D$. citri adults were obtained with foliar neonicotinoid and pyrethroid applications, as compared to the control treatment between 1 and 7 WAT (Tab. 1). In general, the use of active ingredients of these two groups of insecticides reduced the adult population per flush by $50-60 \%$. The control trees had $\approx 1.14$ mean individuals per flush, whereas the trees treated with neoinicotinoids and pyrethroids showed a mean number of individuals of between 0.53 and 0.61 throughout the trial (Tab. 4).

The dynamics of the $D$. citri nymphs were significantly higher in the control trees at 4, 6 and 7 WAT, as compared to the trees foliarly treated with insecticides of both groups (Tab. 2). A mean number of 2.25 nymphs per flush was observed in the control, compared to $0.82-1.22$ individuals obtained in the insecticide treatments when the data were analyzed as mean $D$. citri nymphs per flush (Tab. 4). On the other hand, differences between the treatments were not obtained for the population dynamics of the $D$. citri eggs throughout the trial (Tab. 3). However, when analyzing the effect of the treatments performed as a mean number of eggs per flush, it was observed that the number of eggs was between 80 and 100\% higher 
Table 1. Population dynamics of adults of ACP (individuals per flush) under different foliar applications of active ingredients in 'Tahiti' lime trees. Applications of treatments were done at 0 and 4 weeks after starting the treatments.

\begin{tabular}{|c|c|c|c|c|c|c|c|c|c|}
\hline \multirow{2}{*}{ Treatment } & \multicolumn{9}{|c|}{ Weeks after treatments (WAT) } \\
\hline & 0 & 1 & 2 & 3 & 4 & 5 & 6 & 7 & 8 \\
\hline Control & 1.05 & $1.09 \mathrm{a}$ & $0.85 a$ & $1.05 \mathrm{a}$ & $1.20 \mathrm{a}$ & $1.08 \mathrm{a}$ & $1.32 \mathrm{a}$ & $1.22 \mathrm{a}$ & 1.45 \\
\hline Imidacloprid & 0.99 & $0.30 \mathrm{~b}$ & $0.24 \mathrm{~b}$ & $0.70 \mathrm{ab}$ & $0.20 \mathrm{~b}$ & $0.45 b$ & $0.67 \mathrm{~b}$ & $0.33 \mathrm{~b}$ & 0.82 \\
\hline Bifenthrin & 1.13 & $0.46 \mathrm{~b}$ & $0.43 \mathrm{ab}$ & $0.68 \mathrm{ab}$ & $0.42 \mathrm{~b}$ & $0.47 \mathrm{ab}$ & $0.52 \mathrm{~b}$ & $0.57 \mathrm{ab}$ & 0.75 \\
\hline Thiamethoxan + Lambda cyhalothrin & 1.01 & $0.51 \mathrm{ab}$ & $0.43 \mathrm{ab}$ & $0.66 \mathrm{ab}$ & $0.30 \mathrm{~b}$ & $0.42 \mathrm{~b}$ & $0.33 \mathrm{~b}$ & $0.51 \mathrm{~b}$ & 1.32 \\
\hline Deltamethrin & 0.84 & $0.42 \mathrm{~b}$ & $0.50 \mathrm{ab}$ & $0.38 \mathrm{~b}$ & $0.30 \mathrm{~b}$ & $0.47 \mathrm{ab}$ & $0.50 \mathrm{~b}$ & $0.52 \mathrm{ab}$ & 1.10 \\
\hline \multicolumn{10}{|c|}{ Statistical analysis } \\
\hline Treatment (T) & NS & $* *$ & * & * & $* * *$ & * & $* * *$ & ** & NS \\
\hline Locality (L) & NS & NS & NS & * & * & NS & NS & NS & NS \\
\hline$T \times L$ & NS & NS & NS & $* *$ & NS & NS & NS & NS & NS \\
\hline
\end{tabular}

Means with different letters indicate significant differences according to the Tukey test $(P \leq 0.05)$.

$\mathrm{NS}^{*}{ }^{*}{ }^{* *}$ and ${ }^{* * *}$ : not significant and significant at $P \leq 0.05,0.01$ and 0.001 , respectively.

Table 2. Population dynamics of nymphs of Diaphorina citri (individuals per flush) under different foliar applications of active ingredients in 'Tahiti' lime trees. Applications of treatments were done at $\mathbf{0}$ and 4 weeks after starting the treatments.

\begin{tabular}{|c|c|c|c|c|c|c|c|c|c|}
\hline \multirow{2}{*}{ Treatment } & \multicolumn{9}{|c|}{ Weeks after treatments (WAT) } \\
\hline & $0^{x}$ & 1 & 2 & 3 & 4 & 5 & 6 & 7 & 8 \\
\hline Control & 1.53 & 2.28 & 1.64 & 2.58 & $1.68 \mathrm{a}$ & 2.05 & $2.88 \mathrm{a}$ & $2.28 \mathrm{a}$ & 3.39 \\
\hline Imidacloprid & 1.61 & 0.56 & 0.62 & 1.70 & $0.29 \mathrm{~b}$ & 0.62 & $0.39 \mathrm{~b}$ & $0.57 \mathrm{~b}$ & 1.01 \\
\hline Bifenthrin & 1.86 & 0.81 & 0.90 & 1.38 & $0.65 a b$ & 0.65 & $0.84 \mathrm{~b}$ & $0.66 \mathrm{~b}$ & 1.62 \\
\hline Thiamethoxan + Lambda cyhalothrin & 1.55 & 0.96 & 1.23 & 1.53 & $081 \mathrm{ab}$ & 0.93 & $1.22 \mathrm{ab}$ & $1.64 a b$ & 1.14 \\
\hline Deltamethrin & 1.47 & 0.95 & 1.40 & 1.74 & $0.51 \mathrm{~b}$ & 0.76 & $0.77 \mathrm{~b}$ & $0.80 \mathrm{~b}$ & 1.97 \\
\hline \multicolumn{10}{|c|}{ Statistical analysis } \\
\hline Treatment (T) & NS & NS & NS & NS & * & NS & ** & * & NS \\
\hline Locality (L) & NS & NS & NS & NS & NS & NS & NS & NS & NS \\
\hline$T \times L$ & NS & NS & NS & NS & NS & NS & NS & NS & NS \\
\hline
\end{tabular}

Means with different letters indicate significant differences according to the Tukey test $(P \leq 0.05)$.

$\mathrm{NS}^{*}{ }^{*}$ and $^{* *}$ : not significant and significant at $P \leq 0.05$ and 0.01 , respectively.

Table 3. Population dynamics of eggs of ACP (individuals per flush) under different foliar applications of active ingredients in 'Tahiti' lime trees. Applications of treatments were performed at 0 and 4 weeks after starting the treatments.

\begin{tabular}{|c|c|c|c|c|c|c|c|c|c|}
\hline \multirow{2}{*}{ Treatment } & \multicolumn{9}{|c|}{ Weeks after treatments (WAT) } \\
\hline & $0^{2}$ & 1 & 2 & 3 & 4 & 5 & 6 & 7 & 8 \\
\hline Control & 1.91 & 1.55 & 1.96 & 2.48 & 2.65 & 2.25 & 2.12 & 2.33 & 4.10 \\
\hline Imidacloprid & 1.79 & 0.84 & 1.06 & 1.52 & 0.72 & 1.21 & 0.86 & 0.68 & 1.58 \\
\hline Bifenthrin & 1.34 & 0.97 & 1.05 & 2.08 & 0.73 & 0.84 & 1.22 & 1.21 & 1.64 \\
\hline Thiamethoxan + Lambda cyhalothrin & 2.53 & 1.28 & 1.73 & 1.96 & 0.90 & 1.67 & 1.99 & 1.39 & 2.53 \\
\hline Deltamethrin & 2.38 & 0.88 & 0.98 & 2.74 & 1.28 & 1.96 & 1.68 & 1.31 & 2.42 \\
\hline \multicolumn{10}{|c|}{ Statistical analysis } \\
\hline Treatment (T) & NS & NS & NS & NS & NS & NS & NS & NS & NS \\
\hline Locality (L) & NS & NS & NS & NS & NS & NS & NS & NS & NS \\
\hline$T \times L$ & NS & NS & NS & NS & NS & NS & NS & NS & NS \\
\hline
\end{tabular}

NS: not significant at $P \leq 0.05$. 
in flushes of the control trees $(2.37$ mean individuals per flush) than in the treated trees (1.14-1.78 mean individuals per flush) (Tab. 4).

Table 4. Individuals mean of ACP per flush under different foliar applications of active ingredients in 'Tahiti' lime trees.

\begin{tabular}{|l|c|c|c|}
\hline \multirow{2}{*}{} & \multicolumn{3}{|c|}{ Developmental stages } \\
\cline { 2 - 4 } & Adults & Nymphs & Eggs \\
\hline Control & $1.14 \mathrm{a}$ & $2.25 \mathrm{a}$ & $2.37 \mathrm{a}$ \\
\hline Imidacloprid & $0.53 \mathrm{~b}$ & $0.82 \mathrm{~b}$ & $1.14 \mathrm{~b}$ \\
\hline Bifenthrin & $0.60 \mathrm{~b}$ & $1.04 \mathrm{~b}$ & $1.23 \mathrm{~b}$ \\
\hline $\begin{array}{l}\text { Thiamethoxan }+ \\
\text { Lambda Cyhalothrin }\end{array}$ & $0.61 \mathrm{~b}$ & $1.22 \mathrm{~b}$ & $1.78 \mathrm{ab}$ \\
\hline Deltamethrin & $0.56 \mathrm{~b}$ & $1.15 \mathrm{~b}$ & $1.74 \mathrm{ab}$ \\
\hline \multicolumn{4}{|c|}{ Locality } \\
\hline Apulo & $0.77 \mathrm{a}$ & 1.27 & $1.96 \mathrm{a}$ \\
\hline Jerusalén & $0.61 \mathrm{~b}$ & 1.33 & $1.34 \mathrm{~b}$ \\
\hline \multicolumn{5}{|c|}{ Statistical analysis } \\
\hline Treatment (T) & $* * * \psi$ & $* * *$ & $* * *$ \\
\hline Locality (L) & $* *$ & NS & $* *$ \\
\hline Tx L & NS & NS & NS \\
\hline
\end{tabular}

Means with different letters represent statistically significant differences according to the Tukey test $(P \leq 0.05)$.

NS, ${ }^{* *}$ and ${ }^{* *}$ : not significant and significant at $P \leq 0.01$ and 0.001 , respectively.

Figure 3 shows the differences between the patterns of accumulated adults, nymphs and eggs as a result of the treatments performed throughout the trial. For the accumulation of adults, a lower presence of total individuals $(\approx 50 \%)$ was obtained in the trees with insecticide applications from 1 to 8 WAT (Fig. 3A). On the other hand, the nymph distribution was also conditioned by the use of neonicotinoids and pyrethroids, observing higher accumulations in the control trees from the 4 WAT (Fig. 3B). Finally, the use of insecticides had a more noticeable effect on the accumulation of eggs in flushes of the 'Tahiti' lime trees, where imidacloprid and bifenthrin caused a reduction of $75 \%$ on D. citri oviposition (Fig. 3C).

Differences were not obtained for the efficacy of the imidacloprid, thiamethoxan, bifenthrin and deltamethrin on adult, nymph and egg populations of $D$. citri. In general, the foliar application of both neonicotinoids and pyrethroids showed an efficacy of around $60 \%$ in the different stages of development of the insect (Fig. 4 A, B and C).

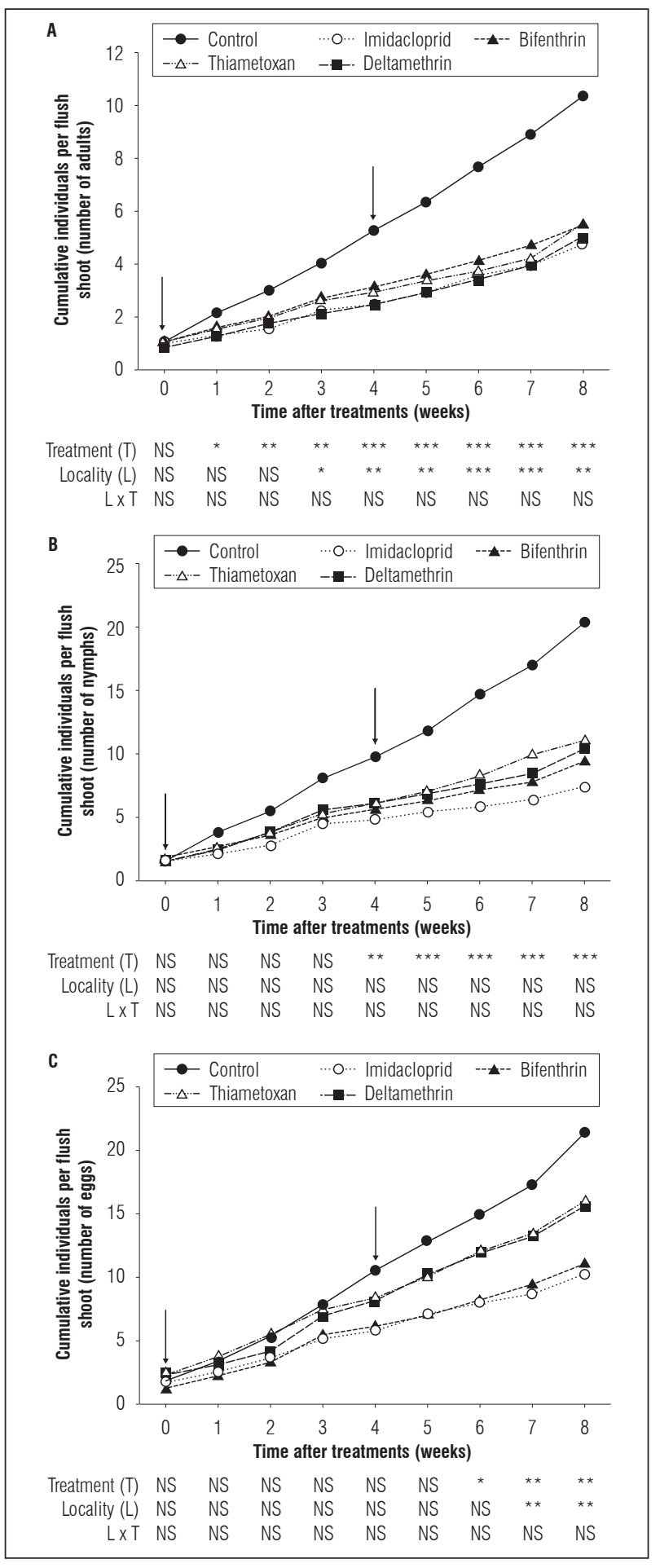

Figure 3. Accumulated ACP individuals for adults (A), nymphs (B) and eggs (C) in C. latifolia trees as a result of foliar treatments of insecticides (control and chemical insecticides) in two localities. NS Not significant; $* * *, * * *$ significant difference at $P \leq 0.001,0.01$ or 0.05 according to the Tukey test. The arrows indicate the timing of the foliar applications. 

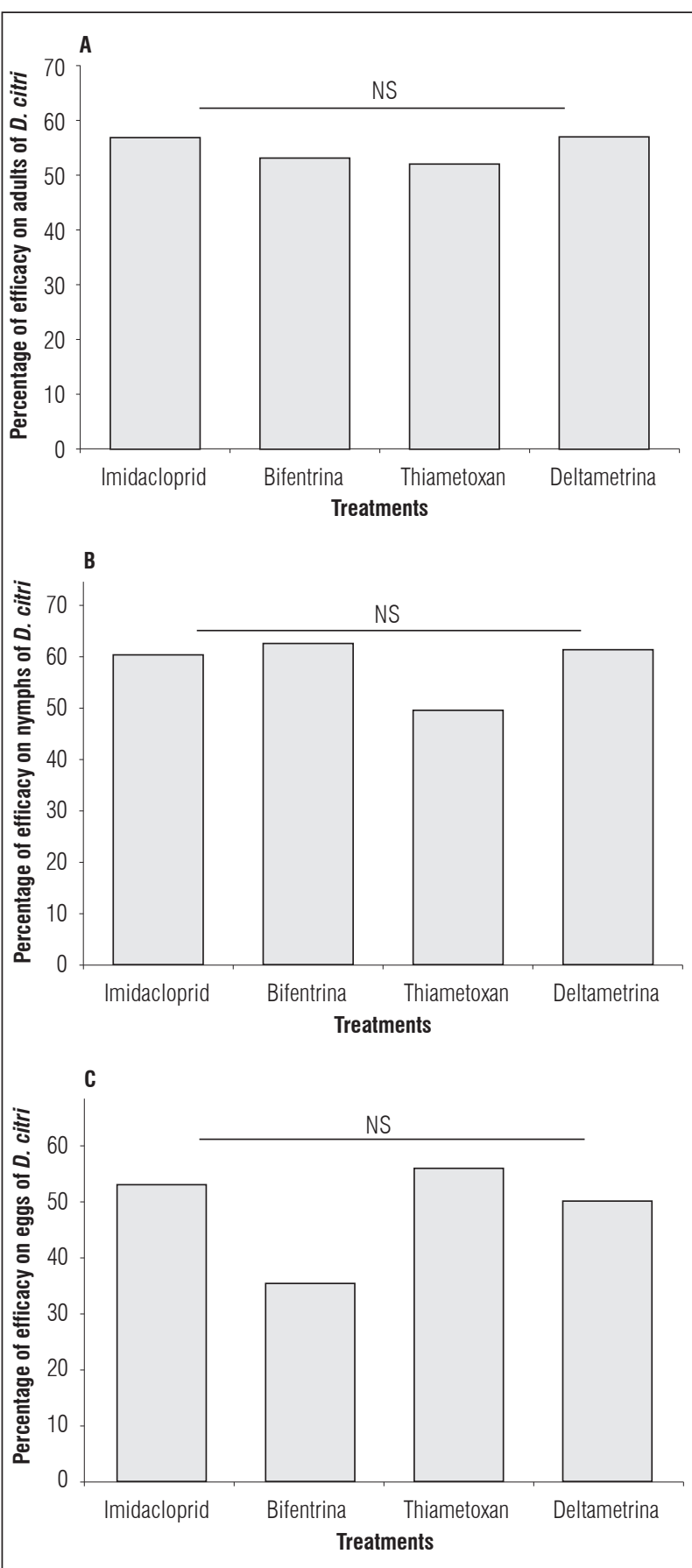

Figure 4. Efficacy percentage of the foliar treatments (neonicotinoids and pyrethroids) on adults (A), nymphs (B6) and eggs (C) of ACP in Citrus latifolia trees. NS Not significant.

\section{Clothianidin evaluation}

Table 5 shows the effect of the use of clothianidin on the population dynamics of $D$. citri adults, nymphs and eggs during a period of 8 weeks. Differences were only observed for the adult number per flush at 7 WAT, where the trees treated with clothianidin showed 1.37 individuals per flush, as compared to 3.12 individuals recorded in the control tree flushes. However, the applications of this insecticide had a greater impact on nymph and egg populations, observing that the number of individuals was generally higher in the untreated trees throughout the trial. Similar trends were obtained when the population dynamics were represented as accumulated individuals where differences between nymphs and eggs were also observed as a result of the treatments (Fig. 5).

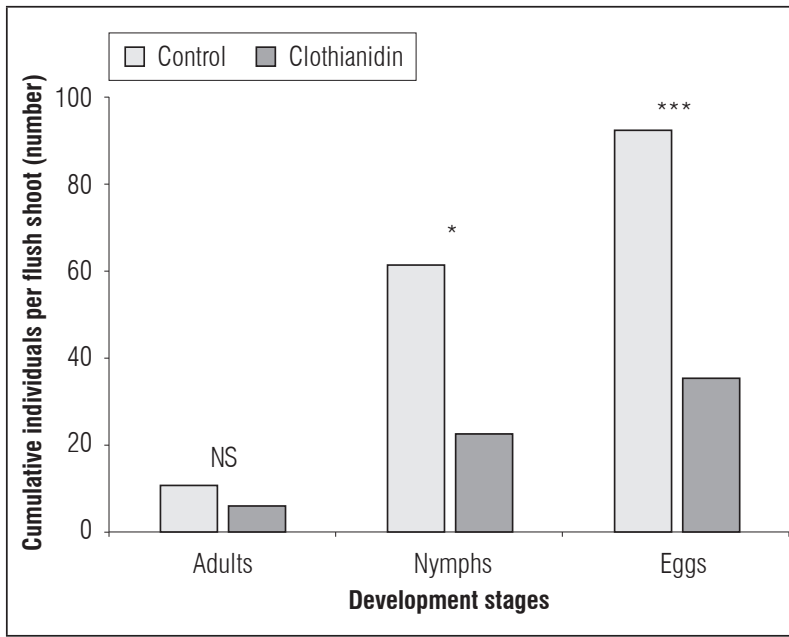

Figure 5. Accumulated individuals of Diaphorina citri (adults, nymphs and eggs) in C. latifolia trees as a result of the foliar treatments of insecticides (control vs. clothianidin) on two farms. Ns Not significant; ${ }^{* *}$ and ${ }^{*}$ significant difference at $\boldsymbol{P} \leq \mathbf{0 . 0 0 1}$ and $\mathbf{0 . 0 5}$ according to the Tukey test.

\section{DISCUSSION}

With the report of the presence of the ACP in Colombia in 2007 and the declaration of the national phytosanitary emergency as a result of the presence of huanglongbing in 2017 (Santivañez et al., 2013; ICA, 2017), the use of insecticides plays an important role in ACP management and the reduction of the spread and severity of HLB (Qureshi et al., 2014). Foliar applications of neonicotinoids (clothianidin, imidacloprid and thiametoxan) have been documented as a tool within IPM programs for the control of ACP populations because they have higher protection (8-9 weeks) (Boina and Bloomquist, 2015). Also, the effect of insecticides belonging to the group of pyrethroids 
Table 5. Population dynamics of adults, nymphs and eggs of ACP (individuals per flush) in 'Tahiti' lime trees treated with insecticide (Clothianidin) and control. Applications of treatments were done at $\mathbf{0}$ and 4 weeks after starting the treatment.

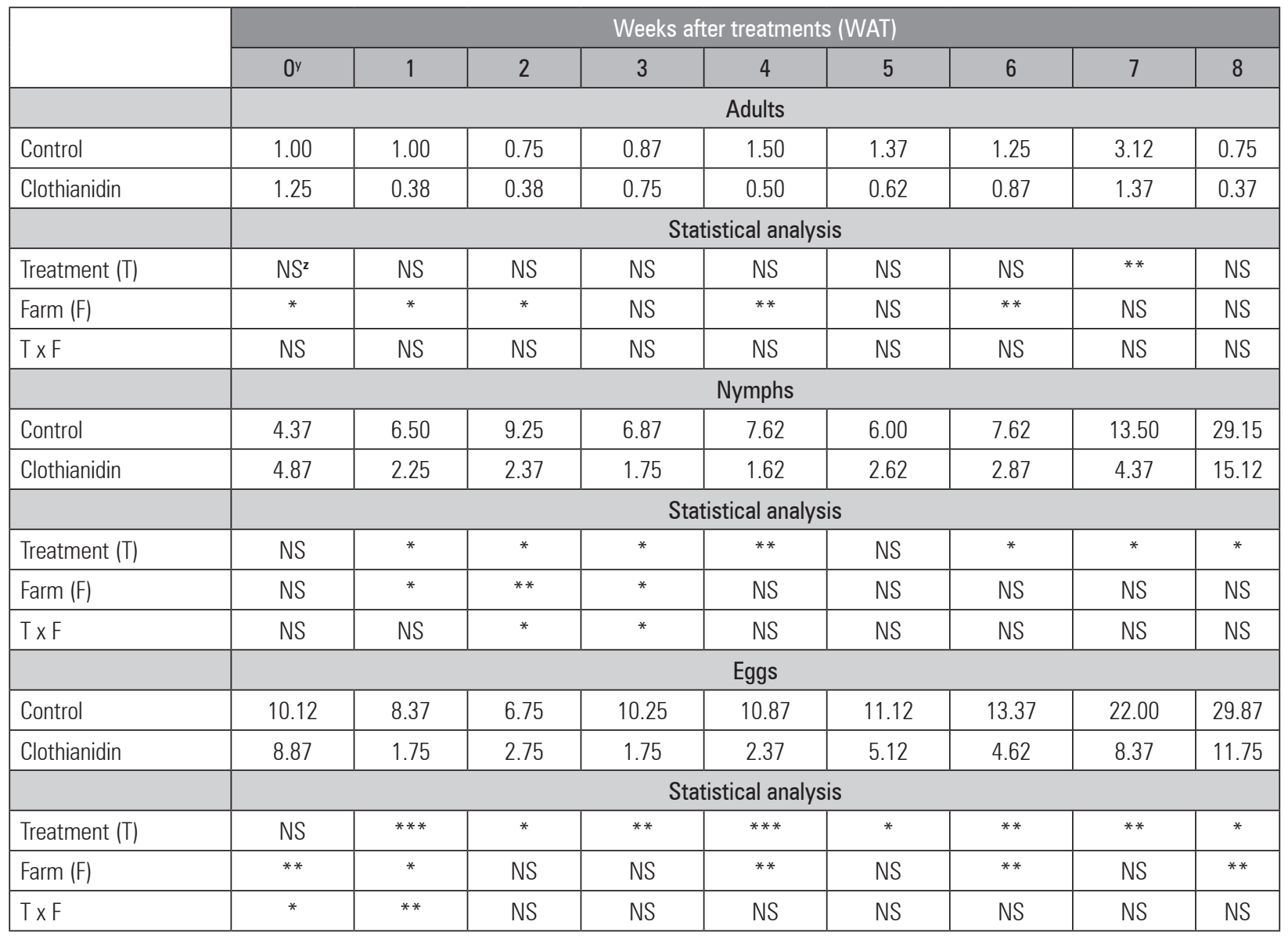

$\mathrm{NS}^{*}{ }^{*}{ }^{* *}$ and ${ }^{* * *}$ : not significant and significant at $P \leq 0.05 ; 0.01$ and 0.01 , respectively.

(bifenthrin and deltamethrin) has also been evaluated for consideration in management programs of this insect in citrus crops in recent years (Yamamoto et al., 2009; Chen and Stelinski, 2017a). Consequently, field studies that evaluate a wide range of products with different action mechanisms that allow product rotations with the purpose of reducing populations and delaying resistance processes are necessary for growers (Qureshi et al., 2014; Chen and Stelinski, 2017b).

The application of imidacloprid showed a higher control effect on the population of accumulated eggs and nymphs, as compared to the other treatments in the present study (Fig. 1 and 3). The above could be due to the fact that imidacloprid can remain active in leaf tissue for 6 to 8 weeks (Castle et al., 2005). Studies carried out by Gatineau et al. (2010) also observed that the use of imidacloprid mainly affected the development of immature states. Qureshi et al. (2014) observed a reduction of $76-100 \%$ in the population of nymphs when Citrus sinensis (L.) trees were treated with neonicotinoids (imidacloprid). Boina et al. (2009) reported that ACP populations can be exposed to sub-lethal concentrations of systemic insecticides such as imidacloprid because the residuality of this molecule in citrus trees over time, which may affect the biology of the insect. The same authors also stated that sub-lethal concentrations of imidacloprid affected the longevity, fertility and fecundity of APC adults, as well as the time of development and survival of nymphs.

Pyrethroids are neurotoxic insecticides widely used in crop protection (Davies et al., 2007). In the present study, the use of bifenthrin and deltamethrin showed efficacy percentages around $60 \%$ in the control of D. citri adults and nymphs. Pardo et al. (2017) 
also observed susceptibility in ACP adult and nymph populations as a result of the use of bifenthrin and argued that this susceptibility may be due to the fact that this compound has been little used in the studied region. The above information can also help to understand the low resistance that $D$. citri presented in the area of the present study since a reduction of the susceptibility of the insect under a high use of this molecule has been reported in other locations in the Americas (Chen and Stelinski, 2017a).

Clothianidin had a mainly ovicidal effect over time (Tab. 5). Hoffmann et al. (2008) also reported that foliar applications of this molecule had an ovicidal effect on Conotrachelus nenuphar. The ovicidal activity may be related to the octanol-water partition coefficient $\left(K_{o w}\right)$ of this compound since the lipid layers of the insect chorion provide a general barrier for hydrophilic compounds (low $K_{\text {ow }}$ ) (Smith and Salkeld, 1966). Clothiadinin has a positive distribution coefficient and, therefore, is able to move through the chorion better (Hoffmann et al., 2008).

In summary, the present study showed that foliar applications of pyrethroids (bifenthrin) and neonicotinoids (imidacloprid) had a percentage of efficacy higher than or equal to $60 \%$ over the control of ACP adults and nymphs. On the other hand, the use of clothianidin showed a higher control of eggs. The results suggest that the rotation of these active ingredients could be a tool to reduce populations and delay resistance processes to reduce the spread of HLB in 'Tahiti' lime orchards established under tropical dry forest conditions.

Conflict of interests: this manuscript was prepared and reviewed with the participation of the authors, who declare that there exists no conflict of interest that puts the validity of the presented results at risk.

\section{BIBLIOGRAPHIC REFERENCES}

Boina, D.R., E.O. Onagbola, M. Salyani, and L.L. Stelinski. 2009. Antifeedant and sublethal effects of imidacloprid on Asian citrus psyllid, Diaphorina citri. Pest Manag. Sci. 65, 870-877. Doi: 10.1002/ps.1767

Boina, D.R. and J.R. Bloomquist. 2015. Chemical control of the Asian Citrus Psyllid and of Huanglongbing disease in citrus. Pest Manag. Sci. 71, 808-823. Doi: 10.1002/ ps.3957

Castle, J.S., F.J. Byrne, J.L. Bi, and N.C. Toscano. 2005. Spatial and temporal distribution of imidacloprid and thiamethoxam in citrus and impact on Homalodisca coagulate populations. Pest Manag. Sci. 61, 75-84. Doi: $10.1002 /$ ps.949

Chen, X.D. and L.L. Stelinski. 2017a. Rapid detection of insecticide resistance in Diaphorina citri (Hemiptera: Liviidae) populations, using a bottle bioassay. Fla. Entomol. 100, 124-133. Doi: 10.1653/024.100.0118

Chen, X.D. and L.L. Stelinski. 2017b. Resistance management for Asian Citrus Psyllid, Diaphorina citri Kuwayama, in Florida. Insects 8, 103. Doi: 10.3390/ insects8030103

Cocco, A. and M.A. Hoy. 2008. Toxicity of organosilicone adjuvants and selected pesticides to the Asian citrus psyllid (Hemiptera: Psyllidae) and its parasitoid Tamarixia radiata (Hymenoptera: Eulophidae). Fla. Entomol. 9, 610-620. Doi: 10.1653/0015-4040-91.4.610

Davies, T.G.E., L.M. Field, P.N.R. Usherwood, and M.S. Williamson. 2007. DDT, pyrethrins, pyrethroids and insect sodium channels. IUBMB life 59, 151-162. Doi: 10.1080/15216540701352042

Ebratt-Ravelo, E.E., L.T. Rubio-González, V.A. Costa, A.P. Castro-Ávila, E.M. Zambrano-Gómez, and J.E. Ángel-Díaz. 2011. Diaphorina citri (Kuwayama, 1907) and Tamarixia radiata (Waterson, 1922) in citrus crops of Cundinamarca, Colombia. Agron. Colomb. 29, 487-493.

Elbert, A., M. Haas, B. Springer, W. Thielert, and R. Nauen. 2008. Applied aspects of neonicotinoid uses in crop protection. Pest Manag. Sci. 64, 1099-1105. Doi: 10.1002/ps.1616

Gatineau, F., F. Bonnot, T.T.H. Yen, N.D. Tuyen, and N.T.N. Truc. 2010. Effects of imidacloprid and fenobucarb on the dynamics of the psyllid Diaphorina citri Kuwayama and on the incidence of Candidatus Liberibacter asiaticus. Fruits 65, 209-220. Doi: 10.1051/fruits/2010017

Gómez, K.A. and A.A. Gómez AA. 1984. Statistical procedures for agricultural research. John Wiley \& Sons, Toronto, Canada.

Henderson, C.F. and E.W. Tilton. 1955. Tests with acaricides against the brown wheat mite. J. Econ. Entomol. 48, 157-161. Doi: 10.1093/jee/48.2.157

Hernández-Fuentes, L.M., M.A. Urias-López, J.I. López-Arroyo, R. Gómez-Jaimes, and N. Bautista-Martínez. 2012. Control químico de Diaphorina citri Kuwayama (Hemíptera: Psyllidae) en Lima Persa Citrus latifolia Tanaka. Rev. Mex. Cienc. Agríc. 3, 427-439.

Hoffmann, E.J., S.M. Middleton, and J.C. Wise. 2008. Ovicidal activity of organophosphate, oxadiazine, neonicotinoid and insect growth regulator chemistries on northern strain plum curculio, Conotrachelus nenuphar. J. Insect Sci. 8, 1-6. Doi: 10.1673/031.008.2901

ICA (Instituto Colombiano Agropecuario). 2015. Resolución 2390 de 2015, Por medio de la cual se declara el estado de emergencia fitosanitaria en el territorio 
nacional por la presencia de adultos de Diaphorina citri infectados con la bacteria de la enfermedad del HLB de los cítricos. Bogota, Colombia.

ICA (Instituto Colombiano Agropecuario). 2017. Resolución número 00007109 de 2017, por medio de la cual se declara el estado de emergencia fitosanitaria en el territorio nacional por la presencia de la enfermedad conocida como Huanglongbing (HLB) de los cítricos. Bogota, Colombia.

Langdon, K.W. and M.E. Rogers. 2017. Neonicotinoid-induced mortality of Diaphorina citri (Hemiptera: Liviidae) is affected by route of exposure. J. Econ. Entomol. 110, 2229-2234. Doi: 10.1093/jee/tox231

Maienfisch, P., M. Angst, F. Brand, W. Fischer, D. Hofer, H. Kayser, W. Kobel, A. Rindlisbacher, R. Senn, A. Steinemann, and H. Widmer 2001. Chemistry and biology of thiamethoxam: a second-generation neonicotinoid. Pest Manag. Sci. 57, 906-913. Doi: 10.1002/ps.365

Pardo, S., A.M. Martínez, J.I. Figueroa, J.M. Chavarrieta, E. Viñuela, Á. Rebollar-Alviter, M.A. Miranda, J. Valle, and S. Pineda. 2017. Insecticide resistance of adults and nymphs of Asian Citrus Psyllid populations from Apatzingán Valley, Mexico. Pest Manag. Sci. 74, 135140. Doi: 10.1002/ps.4669

Qureshi, J.A., B.C. Kostyk, and P.A. Stansly. 2009. Control of Diaphorina citri (Hemiptera: Psyllidae) with foliar and soil-applied insecticides. P. Fl. St. Hortic. Soc. 122, 189-193.

Qureshi, J.A., B.C. Kostyk, and P.A. Stansly. 2014. Insecticidal suppression of Asian Citrus Psyllid Diaphorina citri (Hemiptera: Liviidae) vector of huanglongbing pathogens. PloS One 9, e112331. Doi: 10.1371/journal. pone.0112331

Ruiz-Galván, I., N. Bautista-Martínez, H. Sánchez-Arroyo, and F.A. Valenzuela-Escoboza. 2015. Control químico de Diaphorina citri (Kuwayama) (Hemiptera: Liviidae) en lima persa. Acta Zool. Mex. 31, 41-47. Doi: 10.21829/azm.2015.311503

Santivañez, T., G. Mora Aguilera, G. Diaz Pinilla, J.I. López Arrollo, and P. Vernal Hurtado. 2013. Citrus. Marco estratégico para la gestión regional del Huanglongbing en América Latina y el Caribe. FAO, Santiago.

Sétamou, M., D. Flores, J.V. French, and D.G. Hall. 2008. Dispersion patterns and sampling plans for Diaphorina citri (Hemiptera: Psyllidae) in citrus. J. Econ. Entomol. 101, 1478-1487. Doi: 10.1093/jee/101.4.1478

Sétamou, M., D. Rodriguez, R. Saldana, G. Schwarzlose, D. Palrang, and S.D. Nelson. 2010. Efficacy and uptake of soil-applied imidacloprid in the control of Asian Citrus Psyllid and a citrus leafminer, two foliar-feeding citrus pests. J. Econ. Entomol. 103, 1711-1719. Doi: 10.1603/EC09371

Smith, E.H. and E.H. Salkeld. 1966. The use and action of ovicides. Annu. Rev. Entomol. 11, 331-368. Doi: 10.1146/annurev.en.11.010166.001555

Stansly, P.A., J.A. Qureshi, and B.C. Kostyk. 2015. Evaluation of organophosphate and pyrethroid insecticides for control of Asian Citrus Psyllid and citrus leafminer on oranges, summer, 2014. Arthropod Manag. Tests 40, 1-2. Doi: 10.1093/amt/tsv045

Tiwari, S., R.S. Mann, M.E. Rogers, and L.L. Stelinski. 2011. Insecticide resistance in field populations of Asian citrus psyllid in Florida. Pest Manag. Sci. 67, 1258-1268. Doi: $10.1002 /$ ps.2181

Yamamoto, P.T., M.R. Fellipe, A.L. Sanches, J.H. Coelho, L.F. Garbim, and N.L. Ximenes. 2009. Eficácia de insecticidas para o manejo de Diaphorina citri Kuwayama (Hemiptera: Psyllidae) em citros. BioAssay 4, 1-9. Doi: 10.14295/BA.v4.0.21 